Arq. Bras. Med. Vet. Zootec., v.64, n.2, p.311-317, 2012

\title{
Mummified papyraceous fetuses in the abdominal cavity of an elderly female dog with pyometra
}

[Fetos papiráceos em cavidade abdominal de fêmea canina idosa acometida por piometra]

F.A. Voorwald, C.F. Tiosso, D.J. Cardilli, G.H. Toniollo

Universidade Estadual Paulista "Júlio de Mesquita Filho" - UNESP-Jaboticabal - Jaboticabal, SP

\begin{abstract}
This paper reports on a rare case of fetal papyraceous mummification after asymptomatic uterine rupture in an elderly female dog with pyometra. The patient had a history of mating six months before the examination but no apparent signs of gestation or parturition. Exploratory laparotomy was used to identify a rupture of the left uterine horn and the presence of cystic endometrial hyperplasia and pyometra. Two mummified papyraceous fetuses were observed in the abdominal cavity and had adhered to the spleen, pancreas, intestine and omentum. Ovariehysterectomy and corrective surgery were performed. The patient had remained healthy after uterine rupture until a new estrous cycle and the development of pyometra. Bitches that are 10 years old or more are predisposed to implantation failure, pregnancy or parturition problems and they should not be breed to avoid complications.
\end{abstract}

Keywords: bitch, uterine rupture, fetal mummification, papyraceous

\section{RESUMO}

Relatou-se um caso raro de mumificação fetal papirácea após ruptura uterina assintomática em uma cadela idosa, acometida por piometra. A paciente apresentava histórico de cópula seis meses antes do exame clínico, sem sinais de gestação ou parturição. Na laparotomia exploratória identificaram-se ruptura do corno uterino esquerdo e presença de hiperplasia endometrial cística e piometra. Foram identificados dois fetos mumificados papiráceos na cavidade abdominal, aderidos ao baço, pâncreas, alças intestinais e omento. Realizou-se ovarioisterectomia e cirurgia corretiva. A paciente manteve-se compensada após ruptura uterina, até início de um novo ciclo estral e desenvolvimento de piometra. Cadelas idosas são predispostas à falha na implantação embrionária, problemas durante gestação e parturição, e devem ser excluídas da reprodução para evitar complicações.

Palavras-chave: cadela, ruptura uterina, mumificação fetal, feto papiráceo

\section{INTRODUCTION}

Spontaneous uterine rupture associate with pregnancy is a rare condition that has been reported in a few dogs and cats (Allcock and Penhale, 1952; Darvelid and Forsberg, 1994; Lucas et al., 2003; Hayes, 2004). Linde-Forsberg (2010) reported no incidences of uterine rupture in female dogs secondary to death and/or fetal maceration, but several reports can be found in literature about this complication after erroneous oxytocin or prostaglandin application or manually assisted whelping (Allcock and
Penhale, 1952; Jackson, 2004a; Hajurka et al., 2005).

Spontaneous uterine rupture is considered an obstetrical emergency that results in high rates of morbidity and loss of fertility as a consequence of hysterectomy, as well as neonatal and maternal mortality. Uterine rupture normally occurs during the periparturient period due to trauma or spontaneously in predisposed uterus due to weakening of the epithelium by degenerated areas, obstruction, necrosis, cystic endometrial hyperplasia, uterine torsion, uterine

Recebido em 1 de novembro de 2011

Aceito em 12 de janeiro de 2012

E-mail:voorwald@gmail.com 
epithelium defects, fetal or maternal dystocia, fetal overload, careless obstetrics procedures, dead fetus, erroneous oxytocin or prostaglandin application, myometrial impairment after bacterial infection or surgical scars from cesarean section or other uterine surgeries (Allcock and Penhale, 1952; Hayes, 2004; Jackson, 2004a; Hajurka et al., 2005; Morey, 2005; Linde-Forsberg, 2010), because scar fibrous connective tissues do not have the capacity to grow and stretch like the fibers of normal uterine myometrium tissue (Ofir et al., 2004).

The patient can present clinical signs of abdominal distension, pain, hemorrhagic vaginal discharge, abnormal hemodynamics, reduced uterine activity and sudden reduction in fetal heart rate (Allcock and Penhale, 1952; Hayes, 2004; Jackson, 2004a; Hajurka et al., 2005; González-Domínguez et al., 2010). Extrusion of the fetus into the abdominal cavity can occur in extensive uterine rupture, resulting in intestinal compression, severe adhesions, aseptic septic peritonitis and hemorrhage (GonzálezDomínguez et al., 2010). The diagnosis of uterine rupture is made through the animal's history, clinical signs, laboratory tests, abdominal ultrasound and radiography, but a definitive diagnosis is possible through exploratory laparotomy (GonzálezDomínguez et al., 2010). Treatment consists of ovariohysterectomy, removal of the fetuses, fluid replacement and antibiotic therapy (LindeForsberg, 2010).

A case of uterine rupture and papyraceous fetal mummification was reported, diagnosed four months after the expected date of delivery, in the abdominal cavity of an elderly female dog with pyometra.

\section{CASE REPORT}

A ten-year-old Fila Brasileiro bitch weighing $30 \mathrm{~kg}$ with a history of estrus and mating six months before the examination, without signs of gestation, fetal exposure or signs of parturition, was presented to the Veterinary Hospital. Due to the absence of parturition or clinical signs, the owner had not taken the animal to emergency care, until four months after the expected date of parturition. The owner reported apathy, anorexia, vomiting, hematochezia, polydipsia, polyuria and purulent vaginal discharge over the 15 days before hospitalization. Physical examination revealed cachexia, severe abdominal tenderness to palpation, the presence of a solid structure in the abdominal cavity, lymphadenomegaly, $8 \%$ dehydration and pale mucous membranes.

Hematology revealed leukocytosis, absolute neutrophilia and evidence of leukocyte toxicity characteristic of suppurative inflammatory exudation. The patient presented normochromic normocytic anemia characterized by reduced numbers of red blood cells, hemoglobin and hematocrit, which was most likely due to blood loss subsequent to uterine rupture and passage of red blood cells into the uterine lumen by diapedis. The anemia could also be due to suppression of the erythroid, myeloid and megakaryocytic lineages in the bone marrow, which was due to the toxic effects of a bacterial uterine infection (Faldyna et al., 2001; Kustritz, 2005).

Biochemical tests revealed hyperproteinemia resulting from dehydration or increased synthesis of acute phase proteins and antibodies in response to bacterial infection and inflammation. The patient's hypoalbuminemia was due to a lack of protein ingestion consequent to anorexia as a result of decreased liver synthesis of albumin, hemorrhages, protein loss due to peripheral edema caused by vasculitis or compensation to maintain osmotic pressure caused by increased globulins. Biochemical tests indicated normal levels of creatinine, urea, alkaline phosphatase and alanine aminotransferase. A urine exam showed hematuria, leukocyturia, high urine density and large amounts of transitional epithelial cells in the urinary sediment. Ultrasonographic examination and abdominal radiography revealed two mummified fetuses in the abdominal cavity and images suggested cystic endometrial hyperplasia with anechoic and hypoechoic content in the uterine horn. Electrocardiography and echocardiography revealed changes consistent with hydroelectrolytic disorder and ruled out the presence of severe heart disease. Invasive blood pressure was monitored. A rigorous clinical evaluation with the measurement of physiological parameters and blood tests for arterial hemogasometric evaluation and levels of lactate and glucose was done, and the animal had 
tachycardia, hypotension, acidemia with triple mixed acid-base disturbance, metabolic acidosis, hypochloremic metabolic alkalosis, hypoalbuminemia and respiratory acidosis due to diaphragmatic compression.

The exploratory laparotomy revealed two papyraceous fetuses in the abdominal cavity, adhered to the spleen, pancreas, intestine and omentum. The pancreas was divided into two halves: a vitalized fragment in the anatomical position and a non-vitalized fragment adhered to the fetuses (Figure 1). A left uterine horn rupture that started $3 \mathrm{~cm}$ caudal to the uterine tube and extended up to the uterine bifurcation was identified (Figure 2). The remnant uterine tissue was scarred, which allowed an accumulation of purulent material in $3 \mathrm{~cm}$ of the left cranial portion of the remnant uterine cavity. The right uterine horn presented hyperplasia with serosanguinous content.

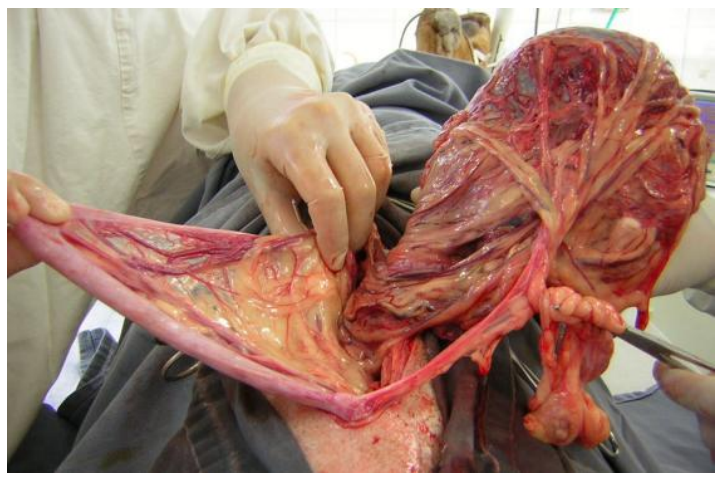

Figure 1. Bitch. Exploratory laparotomy revealed uterine rupture, fetuses in the abdominal cavity and the pancreas divided into a vitalized fragment in the anatomical position and a non-vitalized fragment adhered to the fetuses.

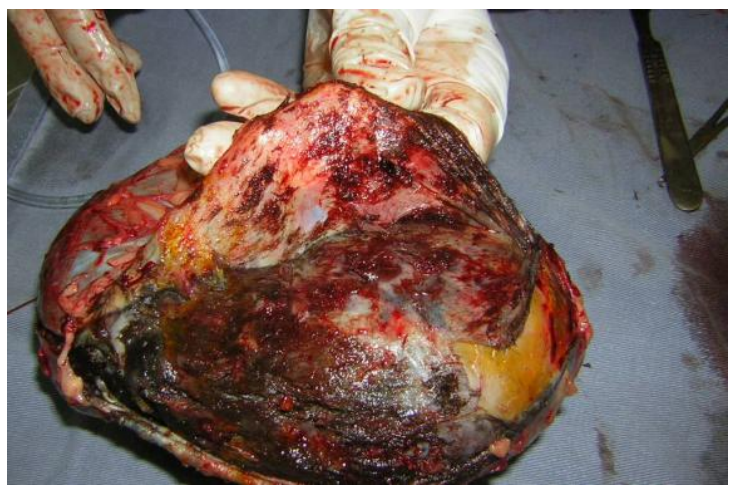

Figure 3. Bitch. Fetal membranes adhered to dehydrated fetuses.
The papyraceous fetuses were dehydrated, without odor or secretions and surrounded by a dark capsule with a wet surface that was formed by the fetal membranes that had adhered to the dehydrated fetuses (Figure 3, 4). Ovariohysterectomy was performed, the fetuses and the necrotic portion of the pancreas were removed, the adherences were released and omentalized with caution and the intestine was involved by the mesentery to prevent further adherences.

An immediate postoperative hemogasometric evaluation demonstrated mild acidemia, eucapnia, chlorine increase and anion gap reduction accompanied by a base excess increase. The animal remained in the inpatient ward at the Veterinary Hospital under treatment and intensive monitoring and presented clinical improvement immediately after the operation.

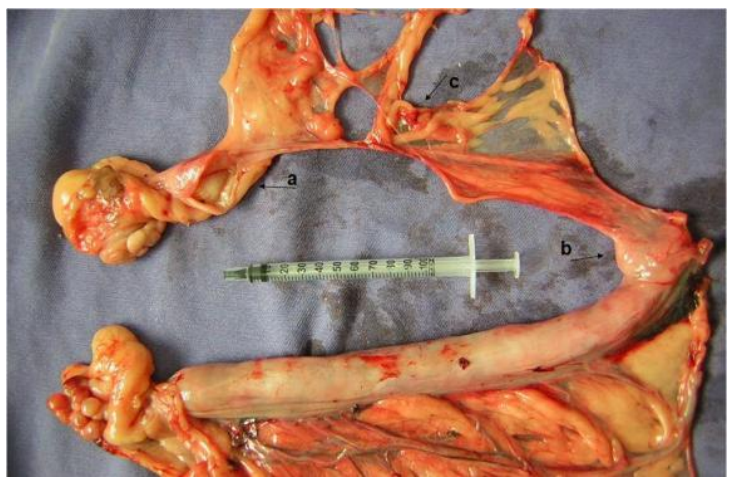

Figure 2. Bitch. The remnant cranial portion of the left uterine horn disrupted $3 \mathrm{~cm}$ caudal to the uterine tube with purulent content (arrow a), up to the uterine bifurcation (arrow b), mesometrium integrity (arrow c) and hyperplastic right uterine horn.

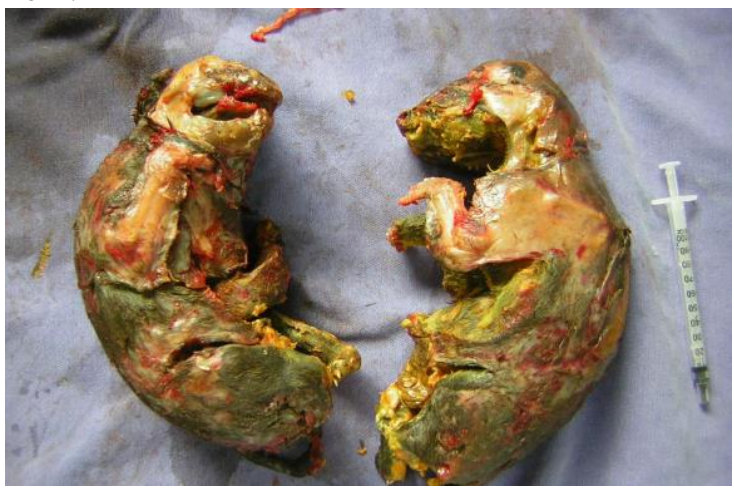

Figure 4. Bitch. Two papyraceous fetuses. 


\section{DISCUSSION}

Spontaneous uterine rupture in pregnant bitches usually occurs during the periparturient period, caused by excessively large doses of oxytocin (Jackson, 2004a; Hajurka et al., 2005). It is believed that in the case described in this report, the uterine rupture occurred in the puerperium, after the failure of the cervix to open, dystocia, fetal death and onset of the mummification process.

Fetal mummification is a sterile process due to morphological changes of the retained dead fetus after the first third of the pregnancy, in the presence of a mature foetal skin resistant to autolysis (Johnston and Raksil, 1987; Johnston et al., 2001a; Jackson, 2004a,b; Grunert et al., 2005; Linde-Forsberg, 2010). Occuring as a consequence of not opening the birth canal, fetal death, placental fluid absorption, progressive dehydration of the dead foetus, with fetal membrane adhesion to the dehydrated fetuses without fetal expulsion (Johnston e Raksil, 1987; Johnston et al., 2001a; Nascimento and Santos, 2003; Jackson, 2004a,b; Grunert et al., 2005; Kennedy and Miller, 2007; Linde-Forsberg, 2010).

Papyraceous fetal mummification occurs when the placenta and fetus acquire the characteristics of papyrus due to dehydration. The placental fluids are absorbed and the fetal membranes adhere to the dehydrated fetus, allowing the formation of a dark tissue with a wet surface without odor or secretions (Johnston and Raksil, 1987; Johnston et al., 2001a; Nascimento and Santos, 2003; Jackson, 2004b; Grunert et al., 2005; Kennedy and Miller, 2007). This is a rare condition described secondary of impaired blood flow to the placenta and umbilical cord due to cord or uterine torsion, trauma, transplacental infections, toxins in the maternal diet or placental dysfunction. Johnson (1987) described fetal mummification as a complication of hypothyroidism in a litter of Borzois, and Johnston and Raksil (1987) and Johnston et al. (1989) demonstrated sex chromosome abnormalities, including triploidy (XXX) and mosaicism (XXY, XXYY), in mummified fetuses in bitches.

It is believed that the female in this report developed papyraceous mummification after dystocia during the second stage of an unproductive labor and fetal death, which is demonstrated by the complete formation of the fetuses. Because the patient experienced papyraceous fetal mummification, which is a sterile process that occurs in the uterine lumen, it is possible that there was no opening of the cervix during labor (Johnston et al., 2001b). The patient did not present clinical manifestations of labor, which may have been consequent to maternal dystocia due to primary uterine atony. Poor abdominal muscle tone occurs in elderly female dogs and results in difficulty in producing uterine contractions in the second stage of labor (Jackson, 2004a,b). It is believed that one or two fetuses fail to produce sufficient ACTH and cortisol to initiate the birth process (Johnston et al., 2001a; Linde-Forsberg, 2010).

The rupture of the left uterine horn may have occurred during the second phase of uterine involution, which is characterized by resorption and tissue dissolution, reduction in the volume of the organ and the myometrial and endometrial thickness, preparing the body for a new pregnancy (Al-Bassam et al., 1981; Arthur et al., 2009). During uterine development in pregnancy, proteolytic enzymes are stored intracellularly in granules that are stabilized by progesterone, which prevents cytoplasmic proteolysis. With the reduction of serum progesterone levels during the puerperium, the stability of these granules in the cells is disrupted, initiating dissolution of the proteins accumulated in the cells during pregnancy via the release of proteases (Al-Bassam et al., 1981; Grunert et al., 2005). Uterine involution depends on myometrial contractions, which are responsible for the elimination of lochia (uterine discharge), continuous prostaglandin F2 $\alpha$ release, elimination of bacterial infection and endometrial regeneration. Due to all of these physiological processes and absorption, dissolution, proteolysis and contractions, the uterine horn is fragile during the involution process in the puerperium. In this case report, these factors were associate with reduced myometrial resistance in elderly female dogs, which occurs due to glandular tissue penetration that arises from hyperplastic overgrowth of the endometrium (Schlafer and Miller, 2007), and associated with a possibility of uterine rupture if the luminal content is different from lochia, which is composed of mucus, blood, placental 
membranes, uterine epithelium and fetal fluids (Al-Bassam et al., 1981; Arthur et al., 2009).

The progressive degenerative process in the development of cystic endometrial hyperplasia, which is due to fibrosis and glandular distension, has been proposed as an initial lesion of pyometra in elderly female dogs, which is mediated by progesterone and exacerbated by estrogen (De Bosschere et al., 2001). Nomura and Nishida (1998) demonstrated that the paradigm of progesterone resulting in cystic endometrial hyperplasia, which results in pyometra, may not always be correct; instead, bacteria may be the initial causative agent of pyometra. A subclinical infection of the uterus or endometrium caused by foreign bodies at the end of estrus or during the first half of diestrus provides the stimulus to begin the process of excessive endometrial hypertrophy and hyperplasia. The secretions that result from glandular proliferation in the endometrium may initiate the development of pyometra or mucometra if the causative agent is or is not a bacterium, respectively (De Bosschere et al., 2001). The patient in this case was an elderly female dog that had cystic endometrial hyperplasia on both uterine horns. The right horn presented hyperplasia with serosanguinous content, without bacterial infection; and the left remnant uterine horn content cystic endometrial hyperplasia and pyometra, probably predisposed by foreign aseptic body remained from the mummification and chronic hyperplasia condition, infected via hematogenous.

The incidence of dystocia is around 5\% overall, but reaches almost $100 \%$ in some breeds of dogs (Linde-Forsberg, 2010). Elderly female dogs are predisposed to maternal and fetal dystocia, decreased oocyte quality, decreased pregnancy rates, decreased numbers of puppies per parturition, as well as an increased occurrence of embryonic mortality, congenital malformations, abortion, stillbirth and postpartum death due to poor gamete quality and difficulty with pregnancy maintenance (Packer et al., 1998; Hafez, 2004; Jackson, 2004b; Rocha et al., 2006). Elderly female dogs present endometrial and myometrial dysfunction, due to cystic endometrial hyperplasia which convert endometrium to a cystic and/or hyperplastic tissue, which interferes with the uterine vascularization required for embryonic implantation, development and maintenance (Danilovich and Sairam, 2006). The integrity of microvascular network and the structural organization of the endometrial glands are important in the beginning of gestation for the blastocyst-uterine interaction, and during gestation for development and maintenance (Schlafer and Gifford, 2008; Ambrósio et al., 2011; Crosier et al., 2011). The endometrial glands delimit the trophoblastic invasion and must secrete histotrofo for the first phase of nutrition to the embryo (Ambrósio et al., 2011). The hyperestimulated increase in cell number and differentiation causes cystic and adenomatous changes characteristic of hyperchromasia, pseudostratification, and a high nuclear:cytoplasmic ratio, due to prolonged reproductive cyclicity (Schlafer and Gifford, 2008; Crosier et al., 2011).

It is possible that the patient remained stable despite uterine rupture until a new estrous cycle and pyometra development because papyraceous mummification is a sterile process, but may have induced pyometra due to foreign aseptic body remained from the mummification associated with chronic hyperplasia condition, infected via hematogenous. Treating dystocia as urgent or emergency is essential for maternal and/or fetal survival. Bitches that are 10 years old or more are predisposed to implantation failure, pregnancy or parturition problems and they should not be bred to avoid complications.

\section{ACKNOWLEDGMENT}

The author is grateful to FUNDUNESP Universidade de São Paulo.

\section{REFERENCES}

AL-BASSAM, M.A.; THOMSON, R.G.; O'DONNEL, L. Normal postparum involution of the uterus in the dog. Can. J. Comp. Med., v.45, p.217-232, 1981.

ALLCOCK, J.; PENHALE, B.M. Rupture of the uterus in the bitch. Vet. Rec., v.64, p.357-358, 1952.

AMBRÓSIO, C.E.; BROLIO, M.P.; MARTINS, D.S. et al. Endometrial alterations, early placentation and maternal fetal interaction in carnivores. Rev. Bras. Reprod. Anim., v.35, p.217-228, 2011. 
ARTHUR, G.H.; NOAKES, D.E.; PEARSON, H. (Eds). Veterinary Reproduction and Obstetrics. 9ed. Philadelphia: WB Saunder; 2009. 960p.

CROSIER, A.E.; COMIZZOLI, P.; BAKER, T. et al. Increasing age influences uterine integrity, but not ovarian function or oocyte quality, in the Cheetah (Acinonyx jubatus). Biol. Reprod., v.85, p.243-253, 2011.

DANILOVICH， N.; SAIRAM，M.R. Recent female mouse models displaying advanced reproductive aging. Exp. Gerontol., v.41, p.117122, 2006.

DARVELID, A.W.; LINDE-FORSBERG, C. Dystocia in the bitch: a retrospective study of 182 cases. J. Small Anim. Pract., v.35, p.402407, 1994.

DE BOSSCHERE, H.; DUCATELLE, R.; VERMEIRSCH, H. et al. Cystic endometrial hyperplasia-pyometra complex in the bitch: should the two entities be disconnected? Theriog., v.55, p.1509-1519, 2001.

FALDYNA, M.; LAZNICKA, A.; TOMAN, M. Imunossupression in bitches with pyometra. $J$. Small Anim. Pract. v.42, p.5-10, 2001.

GONZÁLEZ-DOMÍNGUEZ, M.S.; HERNÁNDEZ, C.A.; MALDONADO-ESTRADA, J.G. Protective compromise of great omentum in an asymptomatic uterine rupture in a bitch: a case report. Rev. Colomb. Cienc. Pecu. v.23, p.369$376,2010$.

GRUNERT, E.; BIRGEL, E.H.; VALE, G. (Eds). Clinic reproduction and pathology of domestic animals (in Portuguese). 1ed. São Paulo, Brazil: Varela; 2005, 551p.

HAFEZ, E.S.E. (Ed). Animal Reproduction. 7nd edition. São Paulo, Brazil: Manole, 2004. 513p.

HAJURKA, J.; MACAK, V.; HURA, V. et al. Spontaneous rupture of uterus in the bitch at parturition with evisceration of puppy intestine a case report. Vet. Med. - Czech. v.50, p.85-88, 2005.

HAYES, G. Asymptomatic uterine rupture in a bitch. Vet. Rec., v.154, p.438-439, 2004.

JACKSON, P.G.G. Postparturient problems in the $\operatorname{dog}$ and cat. In: JACKSON, P.G.G. (Ed). Handbook of Veterinary Obstetrics. 2ed. London: WB Saunders, 2004a. p.233-237.
JACKSON, P.G.G. Problems of pregnancy. In: JACKSON, P.G.G. (Ed). Handbook of Veterinary Obstetrics. 2ed. London: WB Saunders, 2004b. p.16-29.

JOHNSON, C.A. The effect of maternal illness on perinatal health. Vet. Clin. North Am. Small Anim. Pract., v.17, p.555-566, 1987.

JOHNSTON, S.D.; BUOEN, L.C.; WEBER, A.E. et al. Triploidy $(107, \mathrm{XXX})$ in a stillborn canine pup conceived with frozen semen. J.A.V.M.A., v.194, p.1146-1448, 1989.

JOHNSTON, S.D.; KUSTRITZ, M.V.R.; OLSON, P.N.S. Canine parturition - eutocia and dystocia. In: JOHNSTON, S.D. (Ed). Canine and Feline Theriogenology. 1ed. Philadelphia: WB Saunders; 2001a, p.105-128.

JOHNSTON, S.D.; KUSTRITZ, M.V.R.; OLSON, P.N.S. Disorders of the canine uterus and uterine tubes (oviducts). In: JOHNSTON, S.D. (Ed). Canine and Feline Theriogenology. 1ed. Philadelphia: WB Saunders; 2001b, p.206224.

JOHNSTON, S.D.; RAKSIL, S. Fetal loss in the dog and cat. Vet. Clin. North Am.: Small Anim. Pract., v.17, p.535-554, 1987.

KENNEDY, P.C.; MILLER, R.B. The Female Genital System. In: JUBB, K.V.F.; KENNEDY, P.C.; PALMER, N. (Eds) Pathology of Domestic Animals. 4.ed. San Diego: Academic Press; 2007. p.349-454.

KUSTRITZ, M.V.R. Cystic endometrial hyperplasia and pyometra. In: ETTINGER, S.J.; FELDMAN, E.C. (Eds) Textbook of Veterinary Internal Medicine. 7ed. St Louis, Missouri: Elsevier Saunders, 2010. p.1676-1680.

LINDE-FORSBERG, C. Abnormalities in pregnancy, parturition, and the periparturient period. In: ETTINGER, S.J.; FELDMAN, E.C. (Eds) Textbook of Veterinary Internal Medicine. 7ed. St Louis, Missouri: Elsevier Saunders, 2010. p.1890-1901.

LUCAS, X.; AGUT, A.; RAMIS, F. et al. Uterine rupture in a cat. Vet. Rec., v.152, p.301302, 2003.

MOREY, D.L. Acute peritonitis secondary to traumatic breeding in the bitch. J. Vet. Emerg. Crit. Care. v.16, p.128-130, 2005. 
NASCIMENTO, E.F.; SANTOS, R.L.S. (Eds). Pathology of reproduction of domestic animals (in Portuguese). 2ed. Rio de Janeiro, Brazil: Guanabara Koogan; 2003, 156p.

NOMURA, K.; NISHIDA, A. Histological variations of canine deciduoma induced in non pregnant horn at different stages of unilateral pregnancy. J. Vet. Med. Sci., v.60, p.623-626, 1998.

OFIR, K.; SHEINER, E.; LEVY, A. et al. Uterine rupture: differences between a scarred and an unscarred uterus. Am. J. Obstet. Gynecol. v.191, p.425-429, 2004.

PACKER, C.; TATAR, M.; COLLINS, A. Reproductive cessation in female mammals. Nature, v.392, p.807-811, 1998.
ROCHA, A.A.; BASTOS, R.; CUNHA, I.C.N. et al. Quantity and quality of oocytes recovered from donors bitches of different ages. Theriogenology, v.66, p.1465-1467, 2006.

SCHLAFER, D.H.; GIFFORD, A.T. Cystic endometrial hyperplasia, pseudo-placentational endometrial hyperplasia, and other cystic conditions of the canine and feline uterus. Theriogenology, v.70, p.349-358, 2008.

SCHLAFER, D.H.; MILLER, R.B. Female genital system. In: Maxie, M.G. (Ed). Pathology of Domestic Animals. 5.edition. Edinburgh: Saunders Elsevier, 2007. p.464-465. 